\title{
MANAJEMEN PEMBERDAYAAN \\ DALAM PENINGKATAN MUTU PENDIDIKAN ISLAM DI INDONESIA
}

\author{
Oleh: Fachruddin*
}

\begin{abstract}
The major problem of education in Indonesia is the low quality in any levels, kinds and units of education, such as pre-school, primary, secondary and higher education, including Islamic education. Data show that there was no significant changes in general though few schools and madrasabs show promising quality improvement. Some students from big cities in Indonesia were awarded medals in international Olympic. This article which is inspired by a seminar on management of empowerment in improving quality of education discusses the nature of such management, investigates various factors of involution in education, various efforts in reinventing education quality improvement and reconstruct management of empowerment for the future.
\end{abstract}

\section{PENDAHULUAN}

$\mathrm{P}$ ermasalahan utama pendidikan Indonesia dewasa ini adalah rendahnya mutu pendidikan pada setiap jenjang, jenis dan satuan pendidikan. Baik pada pendidikan anak usia dini, pendidikan dasar, pendidikan menengah dan pendidikan tinggi termasuk didalamnya pendidikan Islam. Berbagai data menunjukkan bahwa kualitas pendidikan Indonesia secara umum pada beberapa tahun terakhir ini masih belum menunjukkan perubahan yang menggembirakan meskipun tidak dapat dipungkiri terdapat beberapa sekolah dan madrasah menunjukkan peningkatan mutu pendidikan yang cukup menggembirakan. Beberapa siswa dari kota kota besar di Indonesia berhasil menyabet medali perak dan perunggu dari kejuaraan olimpiade matematika di Madrid bulan Juli 2008 tahun ini.

Semua pihak sesungguhnya telah menyadari kondisi pendidikan Nasional ini dan telah terbangun suatu pandangan visi bahwa pendidikan adalah kunci sukses pembangunan dan kemajuan suatu bangsa (Fergelind, 274, 1999). Keinginan untuk memposisikan pendidikan sebagai lokomotif penggerak pembangunan dan kemajuan telah lama dikumandangkan dan mengedepankannya sebagai panglima meminjam istilah Tilaar (2002) telah pula dicanangkan. Berbagai upaya telah dilaksanakan mulai dari pembaharuan paradigma pendidikan dan menjabarkannya dalam perangkat perundangan yang menjadi frame work pembaharuan/reformasi pendidikan nasional sampai kepada pelaksanaan pelatihan untuk guru dan peningkatan sarana fasilitas. Namun sebagian besar masih tetap jalan ditempat dan sebahagian lainnya masih memprihatinkan. Agaknya kenyataan inilah yang menggelisahkan semua pihak. Tulisan yang disampaikan pada suatu seminar menggagas peningkatan mutu pendidikan nasional ini adalah suatu bentuk dari kegelisahan dan keterpanggilan untuk

*. Penulis adalah Lektor Kepala dalam Mata Kuliah Pendidikan Islam pada IAIN Medan 
secara produktif berpartisipasi memberikan solusi melakukan manajemen pemberdayaan dalam peningkatan mutu pendidikan tersebut.

Tulisan ini memulai pembahasan dengan mengenal apakah itu manajemen pemberdayaan, mendeteksi berbagai faktor involusi dalam pendidikan, selanjutnya melihat ragam upaya reinventing peningkatan mutu pendidikan dan kemudian dari analisis yang ada dilakukan upaya menkonstruksi manajemen pemberdayaan yang mungkin dilakukan ke depan.

\section{MANAJEMEN PEMBERDAYAAN}

Manajemen menjadi sangat penting untuk menjalankan organisasi mencapai tujuan secara efektif. Pada dasarnya manajemen adalah cara pengelolaan organisasi dengan memanfaatkan sumber daya secara baik dan benar. Penyederhanaan makna ini tentunya tidak boleh menjadikan maknanya menyempit karena itu ada baiknya ditampilkan beberapa pandangan para ahli manajemen. Menurut Stoner manajemen adalah proses perencanaan, pengorganisasian, memimpin, dan mengawasi pekerjaan organisasi dan untuk menggunakan semua sumber daya organisasi yang tersedia untuk mencapai tujuan organisasi yang dinyatakan dengan jelas (Stoner \& Freeman,1992:4) Robbin menyatakan manajemen adalah proses untuk membuat aktivitas terselesaikan secara efisien dan efektif dengan dan melalui orang lain. (Robbin dan Coultar, 1996:6) Sedangkan Dubrin menyatakan manejemen sebagai proses menggunakan sumber daya organisasi untuk mencapai tujuan organisasi melalui fungsi planning dan decision making, organizing, leading dan controlling. Pemanfaatan sumber daya secara optimal sebagaimana diisyaratkan dalam manajemen sesungguhnya menghendaki adanya suatu kompe- tensi yang optimal pula pada seorang manejer untuk mengelola sumber daya baik meliputi: sumber daya pekerja (human resources), keuangan (financial resources), barang dan bangunan (phsycal resources) dan data( informational resources) (Andrew J.Dubrin, 1990:13)

Dewasa ini manajemen telah berkembang sedemikian pesatnya sehingga terdapat ragam manejemen sesuai dengan perkembangan dan konteks spesifiknya antara lain kita mengenal manajemen kewirausahaan, manajemen resiko, manajemen konflik, manajemen stress, manjemen partisipatif, manajemen kinerja. Pada tulisan ini penekannannya pada manajemen pemberdayaan. Untuk memahami lebih dekat manajemen pemberdayaan lebih dahulu harus disamakan persepsi bahwa manajemen jenis ini adalah manejemen yang diterapkan untuk pemberdayaan. Pemberdayaan bermakna memberikan keberdayaan atau kekuatan (give to power) menghadapi berbagai perubahan dan pengaruh perubahan sehingga dalam kondisi apapun dapat berjalan secara optimal efektif efesien mencapai tujuan. Pemberdayaan sesungguhnya adalah artikulasi dari kebutuhan untuk adanya perubahan baik dipengaruhi oleh kekuatan eksternal ataupun internal. Kreitner dan Kinicki menyatakan kekuatan eksternal itu antara lain, (1) demographic charecteristics. Dewasa ini terdapat trend bahwa tenaga kerja makin beragam dan terdapat peluang untuk mengembangkan usaha dalam keberagaman itu secara efektif karenanya organisasi perlu mengelola keberagaman itu secara efektif jika menginginkan mendapat konstribusi dan komitmen maksimum dari perkerjanya. (2) technological advancements, perubahan terjadi karena tersedianya teknologi informasi menjadi daya dorong perubahan yang terbesar untuk perubahan karena itu tidak ada alasan untuk tidak berubah 
bersama kemudahan teknologi itu. (3) market changes perubahan pasar disebabkan berbagai faktor, ekonomi, politik, serta perubahan global lainnya, menyebabkan semua organisasi harus merubah dan mengupayakan perubahan untuk dapat berdaya menghadapi perubahan pasar itu. (4) social and political pressures, terjadi karena perubahan kekuasaan, konflik kepentingan, persaingan bisnis, dan lain sebagainya. Sedangkan kekuatan internal antara lain adalah : (1) human resources problems/ prosfect. Pada ketenagaan ini masalah dapat timbul karena mispersepsi dikalangan pekerja, ketidak puasan kerja, dan lain sebagainya. Organisasi harus mampu merespon masalah ini dengan berbagai pendekatan seperti mendesain pekerjaan, konflik peran, memberi penghargaan prestatif dan partisipasi aktif pekerja. (2) managerial behavior/ decisions adanya konflik antara pimpinan dan bawahan. Perlu upaya untuk interpersonal training ataupun bentuk lain reorganisasi struktural.

Pada dasarnya perubahan terdiri dari dua bentuk perubahan terencana dan perubahan tidak terencana. Menurut Greenberg dan Baron (1997:550) perubahan terencana adalah :

1) Changes in products or service (perubahan dalam produk atau jasa).

2) Changes in organizational size and structur (perubahan dalam ukuran dan struktur organisasi)

3) Changes in administration system (perubahan dalam sistem administrasi).

4) Introductions of new technologies (introduksi teknologi baru)

Sedangkan perubahan tak terencana meliputi:

1) Shifting employee demoghraphics (pergeseran demografis pekerja)

2) Performance gap (kesenjangan kinerja)
3) Goverment regulation (peraturan pmerintah)

4) Global competitions (kompetisi global)

5) Changing economic conditions (perubahan kondisi ekonomi.

6) Advances in technology (kemajuan dalam teknologi)

Perubahan yang terencana dapat mengalami kendala disebabkan perubahan tak terencana. Manajemen perubahan mempertimbangkan berbagai kekuatan internal dan ekternal perubahan termasuk pula kemungkinan effek dari perubahan tak terencana. Untuk meningkatkan mutu pendidikan tentulah perlu didekati dengan mengembangkan prinsip prinsip kerja manajemen pemberdayaan ini.

\section{FAKTOR-FAKTOR INVOLUSI DALAM SISTEM PENDIDIKAN.}

Reformasi di bidang pendidikan yang paling mendasar telah dilakukan adalah melakukan review terhadap sistem pendidikan nasional. Berdasarkan hasil analisis dari berbagai sumber terdapat beberapa faktor yang menyebabkan terjadinya involusi atau penurunan mutu pendidikan dan tidak terjadi peningkatan secara merata, antara lain:

1. Penyelenggaraan pendidikan menggunakan pendekatan production function yang tidak dilaksanakan secara konsekuen. Dilaksanakan dengan hanya melihat dari aspek in-put yang baik akan menghasilkan out-put yang baik . Pada hal sub-sistem proses juga sangat menentukan out-put pendidikan yang baik

2. Penyelenggaraan pendidikan dilakukan secara sentralistik sehingga sekolah sangat tergantung pada keputusan birokrasi, yang berakibat sekolah kehilangan inisiatif untuk mengembangkan dan memajukan lem- 
baga termasuk untuk meningkatkan mutu pendidikan.

3. Minimnya peranserta masyarakat, partisipasi pada umumnya selama ini lebih banyak bersifat dukungan dana bukan pada dukungan proses pendidikan yaitu pada pengambilan keputusan, monitoring, evaluasi dan akuntabilitas (E.Suparman, 2, 2007).

4. Peran guru hanya sebatas tenaga pengajar bukan pembelajar, akibatnya pembelajaran sama sebagai proses pump sistem bukan suatu proses production sistem dimana pengalaman belajar secara optimal diolah menjadi kompetensi dan mampu berkembang dan diaplikasikan untuk kepentingan kehidupan dan peningkatan kualitas hidup.

5. Kelima, kurikulum diposisikan sebagai acuan baku, tidak diposisikan sebagai frame work yang dapat dan harus dikembangkan secara kreatif.

6. Evaluasi cenderung dilakukan pada menilai hasil seyogianya dilakukan secara simultan antara penilaian hasil dan proses.

Dalam memenej pemberdayaan peningkatan mutu keenam faktor ini harus lah dicermati secara akurat dan komprehensif dalam bentuk melakukan reinventing. Untuk selanjutnya dari pencermatan itu dapat disusun upaya untuk melakukan empewering

\section{UPAYA RE-INVENTING PE- NINGKATAN MUTU PENDIDIKAN}

Sampai saat ini ada beberapa upaya yang terus menerus dilakukan antara lain melakukan reformasi yang mendasar dengan mereview undang undang Sistem Pendidikan Nasional no 2 tahun 1989 menjadi UUSPN no 20 tahun 2003 serta melengkapi dengan UU no 14 tahun 2005 tentang Guru dan Dosen serta PP No 19 tahun 2005 tentang Standard Nasional Pendidikan dan peraturan menteri tentang petunjuk pelaksanaan dan teknis berbagai penerapan aturan tersebut.

Berdasarkan aturan tersebut telah dilakukan pendidikan dan pelatihan tenaga guru, program peningkatan kualifikasi guru, pendidikan professi, sertifikasi guru dalam jabatan, akreditasi sekolah, penyediaan dan perbaikan sarana/ prasarana pendidikan, peningkatan mutu manajemen sekolah, peningkatan kesejahteraan guru, dengan mengadakan tunjangan professi dan tunjangan fungsional bagi yang belum tersertifikasi, bantuan bantuan lainnya untuk peningkatan mutu serta pengembangan dan perbaikan kurikulum.

Dalam rangka re-inventing manajemen peningkatan mutu ini pendekatan education production function, sub system in put dan proses harus mendapat penekanan yang signifikan. Di pihak lain untuk proses yang berkualitas diperlukan guru yang dengan kualifikasi sesuai dan berkualitas, berkompetensi yang baik meliputi kompetensi akademik, sosial, personal dan professional. Untuk itu pelaksanaan sertifikasi, pendidikan lanjut, dan pendidikan professi menjadi kebutuhan yang utama. Program ini jelas pekerjaan luar biasa mengingat pendidik di negara ini jumlahnya sangat besar baik guru negeri maupun swasta.

Seiring dengan itu masalah kesejahteraan dan jaminan hidup perlu mendapat perhatian. Berbagai pihak harus memiliki komitmen agar dapat mengupayakan peningkatan kesejahteraan guru yang selama ini sangat rendah, bahkan ada yang menyebutkan di bawah upah minimal regional. Kreitner dan Kinichi (2001:671) memasukkan masalah kesejahteraan atau penghargaan ini (nonreinforcing reward system) sebagai faktor kesepuluh dari resistensi untuk berubah .

Selanjutnya guna mengoptimalkan peran lembaga pendidikan dilakukan 
reorientasi penyelenggaraan pendidikan melalui manajemen berbasis sekolah (school based management) suatu sistem pengelolaan sumber daya sekolah secara serasi mandiri dan melibatkan stoke holder yang terkait dengan sekolah secara langsung dalam proses pengambilan keputusan untuk memenuhi kebutuhan mutu sekolah atau mencapai tujuan mutu sekolah dalam pendidikan nasional.

Penerapan MBS akan memunculkan profil sekolah yang mandiri antara lain:

1. Pengelolaan sekolah akan desentralistik

2. Perubahan sekolah akan lebih didorong oleh motivasi daripada diatur oleh luar sekolah

3. Regulasi pendidikan menjadi lebih sederhana

4. Peranan pengawas bergeser dari mengontrol menjadi mempengaruhi , dari mengarahkan menjadi memfasilitasi dan dari menghindari resiko menjadi mengelola resiko.

5. Manajemen akan mengalami peningkatan.

6. Dalam bekerja akan menggunakan team work.

7. Pengelolaan informasi akan mengarah ke semua kelompok kepentingan sekolah

8. Manajemen sekolah akan lebih menggunakan pemberdayaan dan struktur organisasi akan lebih datar sehingga akan lebih sederhana dan efesien.

Diantara masalah terjadinya involusi pendidikan adalah sistem kurikulum yang hanya bersifat subjek akademik menekankan pencapaian tujuan kurikulum. Pola ini mengantarkan peserta didik menjadi mengetahui tetapi tidak menguasai dan mampu menterapkan ilmu yang dipelajari. Perubahan kurikulum menjadi kurikulum berbasis kompetensi yang dalam aplikasinya menetapkan standar kompetensi lulusan dengan indikator pencapaian yang optimal disesuaikan pada situasi kondisi yang melampaui standar minimal yang ditetapkan. Pola penterapan KBK telah diatur dalam bentuk kurikulum tingkat satuan Pendidikan (KTSP). Penetapan suatu model dan pola tentunya harus dilakukan secara komprehensif tidak boleh sekedar ganti baju atau nama. Secara teoritis kurikulum yang dikembangkan ini sangat memungkinkan untuk meningkatkan mutu pembelajaran dan kualitas pendidikan . Untuk mendukungnya pengenalan, pemahaman dan pelatihan yang intensif dan penterapan berbagai model dan strategi pembelajaran aktif sangat perlu diintensifkan.

\section{MANAJEMEN PEMBERDAYAAN PENINGKATAN MUTU}

Sangat disadari suatu perbaikan atau peningkatan tentu tidak dapat dilakukan dengan proses secara tiba tiba . Menuntut suatu hasil perubahan itu secara instan tentulah tidak arif dan tidak adil. Dari berbagai realita yang terpantau beberapa waktu dari proses continuos improvement ini ada beberapa hal yang harus segera ditata pemberdayaannya antara adalah:

Pertama: keseriusan para tenaga pendidik pada Madrasah untuk meningkatkan kualitas pembelajaran, kualitas diri meliputi kompetensi guru yang ditetapkan. Diperlukan kesadaran yang lahir dari lubuk hati nurani yang paling dalam untuk mengembangkan dirinya menjadi guru yang efektif dan kreatif. Semua upaya pemberdayaan ekternal akan sia sia belaka bila tidak disertai dengan adanya pemberdayaan dari dalam diri guru. Langkah ini perlu diikuti dengan membuat perencanaan pemberdayaan. Menurut Greenberg dan Baron (1997:550) perubahan terencana adalah : 
1) Changes in products or service (perubahan dalam produk atau jasa). Dalam hal ini guru harus meningkatkan mutu kinerjanya dan mutu pembelajaran yang tentunya dimulai dengan meningkatkan kompetensi akademik dan kompetensi professional.

2) Changes in organizational size and structure (perubahan dalam ukuran dan struktur organisasi) tentunya pada tingkat kelas para guru juga harus mengembangkan perencanaan untuk melakukan perubahan perubahan bentuk dan pola organisasi pembelajaran termasuk melakukan pembaharuan dalam memenej kelas.

3) Changes in administration system (perubahan dalam sistem administrasi). Para guru harus pula melakukan perencanaan dalam merubah sistem administrasi pembelajaran menjadi lebih efektif dan inovatif .

4) Introductions of new technologies (introduksi teknologi baru) Untuk ini perlu dimenej kemajuan kemampuan untuk untuk mendisain pembelajaran secara otentik dan mengembangkan kompetensi professi yang lebih akurat dengan memanfaatkan teknologi informasi pada proses pembelajaran.

Untuk itu para guru pendidikan Islam perlu mereview dan menselaraskan pola pembelajaran . Kecenderungan untuk memperjelas pola lama dengan kemasan baru adalah gejala wajar dan umum. Toleransi untuk itu dapat diterima sepanjang tidak menjadi kontra produktif. Karenanya suatu upaya pengorganisasian pengalaman belajar yang kondusif dan full-meaning perlu dilakukan oleh setiap tenaga pendidik.

Kedua: hal yang paling mendasar lainnya dalam pengembangan MBS pada lembaga pendidikan Islam adalah sekolah harus diberdayakan menjadi sekolah efektif yang didukung oleh SDM yang professional. Arah pemberdayaan yang perlu ditempuh adalah membina guru agar memiliki sikap mental dan pandangan bahwa :

1. pekerjaan adalah miliknya.

2. bertanggung jawab

3. memiliki konstribusi terhadap pekerjaannya

4. mengetahui posisi dirinya dan memiliki control terhadap pekerjaannya.

5. pekerjaan merupakan bahagian hidupnya.

Ketiga: Dalam memberdayakan Madrasah/sekolah menjadi madrasah/ sekolah efektif adalah dengan membangun manajeman sekolah dengan karakteristik sebagai berikut.

1. Visi misi yang jelas dan target mutu yang harus sesuai dengan dengan standar yang telah ditetapkan secara lokal.

2. Memiliki out put yang selalu meningkat setiap hari

3. Lingkungan marasah/sekolah yang aman, tertib menyenangkan

4. Seluruh personil memiliki visi dan misi Serta harapan yang tinggi untuk berprestai secara optimal

5. Memiliki evaluasi yang kontiniu dan komprehensif terhadap berbagai aspek akademik dan non akademik.

Keempat: Dalam jangka panjang diperlukan sistem pendidikan tenaga keguruan yang lebih komprehensif. Beberapa pola /model yang banyak dipertimbangkan adalah terselenggarakannya sekolah guru yang sejak dini mendidik bakat dan minat, kepribadian dan wawasan serta ketrampilan keguruan dan keilmuan yang mampu untuk tiap jenjang dan jenis kependidikan. Untuk tenaga pendidik dari non keguruan dikembangkan pendidikan profesi keguruan sedangkan untuk pendidikan tinggi dikembangkan pendidikan tinggi keguruan dan sarjana saintek yang direkrut menjadi guru atau memilih professi keguruan, maka kepada mereka 
sebaiknya mengikuti pendidikan keguruan.

Kelima: dalam menjamin mutu (quality -assu rance) para guru perlu dibekali dengan kemampuan untuk melakukan classroom action research yaitu penelitian tindakan kelas dengan demikian mereka bisa melakukan perbaikan mutu pembelajaran yang dilaksanakannya.

Keenam: upaya untuk meningkatkan mutu haruslah dimulai dengan peningkatan kualitas ketenagaan itu sendiri. Sebagai pekerjaan profesional maka uapaya untuk melakukan penilaian kinerja dan adanya pengakuan professi menjadi suatu tuntutan utama . Dalam hal ini berbagai organisasi professi keguruan agama haruslah memberikan sumbangan yang positif bagi pemberdayaan tenaga pendidik Islam. Selanjutnya program seritifikasi guru dalam jabatan perlu diintensifkan agar dapat memacu para pendidik memperbaiki kualitas diri dan kompetensi.

Ketujuh, mengaitkan kompetensi dengan kompensasi/gaji adalah suatu hal yang wajar. Karena itu kesejahteraan guru dalam upaya peningkatan mutu pendidikan harus dipandang menjadi suatu paket. Dengan kata lain pe- ningkatan mutu pada dasarnya terkait dengan kesejahteraan dan demikian sebaliknya.

Ketujuh prioritas ini dalam mewujudkannya harus dilakukan dalam prinsip kerja manajemen perubahan yang dimulai dengan adanya perubahan perilaku dan budaya organisasi para pendidik.

\section{PENUTUP}

Sebagai sub sistem pendidikan nasional pendidikan Islam yang terselenggara dalam satuan pendidikan agama dalam bentuk Madrasah dan di sekolah serta pendidikan keagamaan tentu perlu mengembangkan manajemen pemberdayaan dalam peningkatan mutu ini dengan berbagai langkah strategis yang dikemukakan.

Perencanaan perubahan sebagai prinsip dasar manajemen pemberdayaan haruslah dijalankan lebih intensif untuk dapat menerapkan policy lanjut dari program continous improvement (peningkatan berkelanjutan) sebagai inti dari manajemen pemberdayaan dan peningkatan mutu pendidikan Islam di Indonesia.

\section{DAFTAR RUJUKAN}


Dubrin,Andrew J. 1990. Essensial of Management,Ohio, South Western Publishing Co.

Depdiknas, Manajemen Peningkatan Mutu Berba sis Sekolah, Buku 1 dan 2, Jakarta

Davies, Brent and Linda Elison. 1999. StrategicDirection and Development of the School, Routledge, New York,

Eman Suparman. 2008. Manajemen Pendidikan Masa Depan. html file, download.

Fergelind, Saha, dalam Albach. 1988. Comparative Education, Mac Milan London.
Greenberg, Jerald and Robert A Baron. 1997. Behavior in Organization, New Jersey, Printice Hall International, Inc.

Robbin Stephen P. 2003. Organization Behavior, New Jersey, Prentice Hall International Inc.

Stoner James A and R.Edward Freeman. 1992. Management, New Jersey, Printice Hall

Tilaar,HAR. 2002. Manajemen Pendidikan Nasional Kajian Pendidikan Masa Depan, PT. Remaja Rosda Karya,

*. Penulis adalah Lektor Kepala dalam Mata Kuliah Pendidikan Islam pada IAIN Medan 